International Journal of Advanced Chemistry, 2(2)(2014) 178-181
International Journal of Advanced Chemistry
Journal home page: $\begin{gathered}\text { www.sciencepubco.com/index.php/IJAC } \\ \text { doi: } 10.14419 / \text { ijac.v2i2.3568 } \\ \text { Research Paper }\end{gathered}$

\title{
Antibacterial activity and phytochemical evaluation of the leaf root and stem bark extracts of parinari curatellifolia (planch. ex benth).
}

\author{
Ugoh Sylvanus ${ }^{1}$ Fatokun Olakunle ${ }^{2 *}$, Jimba Amos ${ }^{1}$, Olajide Olutayo ${ }^{2}$ \\ ${ }^{1}$ Department of Biological Sciences, University of Abuja Nigeria \\ ${ }^{2}$ Chemistry Advanced Laboratory, Sheda Science and Technology Complex, Sheda Abuja, Nigeria \\ ${ }^{2}$ Department of Biological Sciences, University of Abuja Nigeria \\ *Corresponding author E-mail: Olakunlefatokun @yahoo.com
}

\begin{abstract}
The different parts (leaf, root and stem bark) extracts of Parinari curatellifolia were studied to assess phytochemicals, antimicrobial activities and to confirm their traditional medicinal uses. Phytochemical screening of the crude extracts (leaf, root and stem bark) showed the presence of phenols, flavoniods, sterols, terpenoids, carbohydrates and saponnins. The crude extracts were screened for antimicrobial activity against three bacteria, Staphylococcus aureus, Streptococcus mutans and Lactobacillus spp. The minimum inhibitory concentration (MIC) of the methanol extract gave the highest zones of inhibition against the isolates used which revealed activities against $\mathrm{S}$. aureus S. mutans and Lactobacillus spp. The biologically active methanol extract was purified using flash column chromatography. The two fractions (ME1 and ME2) were obtained from the column. Fraction ME1 gave the highest zone of inhibition ranging from $24 \pm 0.6$ $\mathrm{mm}$ to $28 \pm 0.0 \mathrm{~mm}$ against $\mathrm{S}$. mutans. This is significantly $(\mathrm{P} \leq 0.05)$ different from the crude methanol extract with the zone of inhibition ranging from $23 \pm 0.00 \mathrm{~mm}$ to $26 \pm 0.90 \mathrm{~mm}$. The activities of crude extracts were lower compared to that of the separated fractions.
\end{abstract}

Keywords:Parinari curatellifolia, phytochemicals, antimicrobial and medicinal uses

\section{Introduction}

Medicinal plants represent rich sources of antimicrobial agents. Plants are used medicinally in different countries as sources of potent and powerful drugs (Srivastav et. al., 2001.). A range of medicinal plant parts extracts are used as raw drugs and possess varied medicinal properties. The different parts include roots, stem, flowers, fruits, twigs, exudates, leaves and modified plant organs. Parinari curatellifolia belongs to the family of Chrysobalanaceae. It is very widespread, ranging from the south, north and central Africa (Mark et.al.,2002) P. curatellifolia have various uses in ethno medicine; the leaves are used as expectorant, sedative and in the treatment of anemia (Shale et.al.,1999) while the barks are used for vaginal douches, treatment of itching scalp, cough and dandruff (Qasem et.al.,1996). The medicinal uses include treatment of wound infections, cancer, pneumonia, fever, bacterial infections, anti-inflammation, dressing of fracture and dislocation (Kraft et.al., 1996; Steve et.al., 2009). The fruit extract of P. curatellifolia possess cardio- tonic uses for functional heart disease such as hypertension, dyspores as well as for diuretic (Peni,2010). Plants possess metabolites such as are alkaloids, tannins, saponins, flavonoids and phenol compounds (Edeoga et.al.,2005).Therefore, this work was designed to evaluate the phytochemical constituents and antibacterial activity of different parts (leaf, root and stem bark) of P. curatellifolia in aqueous, ethanol and methanol solvents.

\section{Materials and methods}

All solvents and reagents used were of standard grade and the solvents were redistilled before use. Thin Layer Chromatography (TLC) was carried out on pre-coated aluminum sheets $(0.2-0.5 \mathrm{~mm}$ mesh). The spots were visualized using UV light from a UV lamp (UV-254/366 mm) and also by the use of iodine vapour. Flash column chromatography was carried out using silica gel $400 \mathrm{~mm}$ mesh .The media used for the antibacterial screening was nutrient agar using the Agar well diffusion method against the following bacteria, Staphylococcus aureus, S. mutans and Lactobacillus spp. The test organisms are clinical isolates obtained from the Microbiology Laboratory of the University of Abuja Teaching Hospital, Abuja, Nigeria.

\section{Extraction of plant material}

Matured leaves roots and stem bark of P. curatellifolia were collected from Odulo in Bassa Local Government of Kogi State, Nigeria. It was identified and authenticated by a trained Taxonomist in the Department. The plant materials were air dried to a constant weight and grounded into powder. The powdered material (leaf, stem bark and root) were extracted by maceration in water $(400 \mathrm{ml})$, ethanol $(400 \mathrm{ml})$ and methanol $(400 \mathrm{ml})$ for $48 \mathrm{~h}$. The soaked samples were filtered using Whatman's No. 1 filter paper and were concentrated using rotary evaporator.

Phytochemical Screening 
The extracts were subjected to phytochemical screenings (Harborne1998, Evan and Trease (1983). to determine the classes of phytochemical present. (Halihu et al. 2010) .

\section{Antibacterial assay}

The crude extracts of the different solvents and the chromatographic isolates $\mathrm{ME}_{1}$ and $\mathrm{ME}_{2}$ were subjected to antibacterial screening. The zone diameter of inhibition (ZDI) was carried out using the Agar well- diffusion method and the Minimum inhibitory concentrations (MICs) were determined using the macro broth dilution method. ((Halilu et.al. 2010; Peni et al. 2010). The Petri dishes containing Nutrient agar were spread with $0.2 \mathrm{ml}$ of the inoculums. Five millimeter diameter wells were bored on the agar plates using a sterilized stainless steel cork borer and each of the wells were filled with $0.1 \mathrm{ml}$ of the different extracts and incubated at $37^{\circ} \mathrm{C}$ for 24 hours. The experiment was performed in duplicate. Erythromycin was used as positive control.

\section{Minimum inhibitory concentration (MIC)}

The Minimum Inhibitory Concentration (MIC) was determined (Bukar et.al, 2010; Rodrigues et.al, 2005) with a little modification. A loopful of each organism was prepared with normal saline using $0.5 \mathrm{McF}$ arland standards. About $0.1 \mathrm{ml}$ of the different concentrations of the different extracts was aseptically introduced into test tubes containing $2 \mathrm{ml}$ of Nutrient broth. About $0.1 \mathrm{ml}$ of each of the inoculums of the test organisms was also introduced into the different test tubes containing nutrient broth and extracts. The test tubes together with their contents were incubated $37^{\circ} \mathrm{C}$ for $24 \mathrm{~h}$ and were observed for turbidity.

\section{Determination of minimum bactericidal concentration (MBC)}

The different test tubes from the MIC that did not showed any turbidity were then sub-cultured onto nutrient agar plates and incubated at $37^{\circ} \mathrm{Cfor} 24$ hours to observe for bacterial growth

\section{Results}

Table 1: Phytochemical Screening Results for the Crude Extracts Parinari Curatellifolia

\begin{tabular}{|c|c|c|c|c|c|c|c|c|c|}
\hline \multirow[t]{2}{*}{ Phytochemicals } & \multicolumn{3}{|c|}{ Aqueous } & \multicolumn{3}{|c|}{ Ethanol } & \multicolumn{2}{|c|}{ Methanol } & \multirow[b]{2}{*}{ bark } \\
\hline & leaf & root & bark & leaf & root & bark & leaf & root & \\
\hline Saponnins & + & + & + & + & + & + & + & + & + \\
\hline Tannins & + & + & + & + & + & + & + & - & + \\
\hline Alkaloids & + & + & + & + & + & + & + & + & + \\
\hline Balsam & + & + & + & + & + & + & + & + & + \\
\hline Cardiac glycoside & - & + & - & + & + & + & + & + & + \\
\hline Glycoside & - & - & + & + & + & + & - & + & + \\
\hline
\end{tabular}

Table 2: Antibacterial Activity of Aqueous Extracts of P. Curatellifolia Against the Test Organisms.

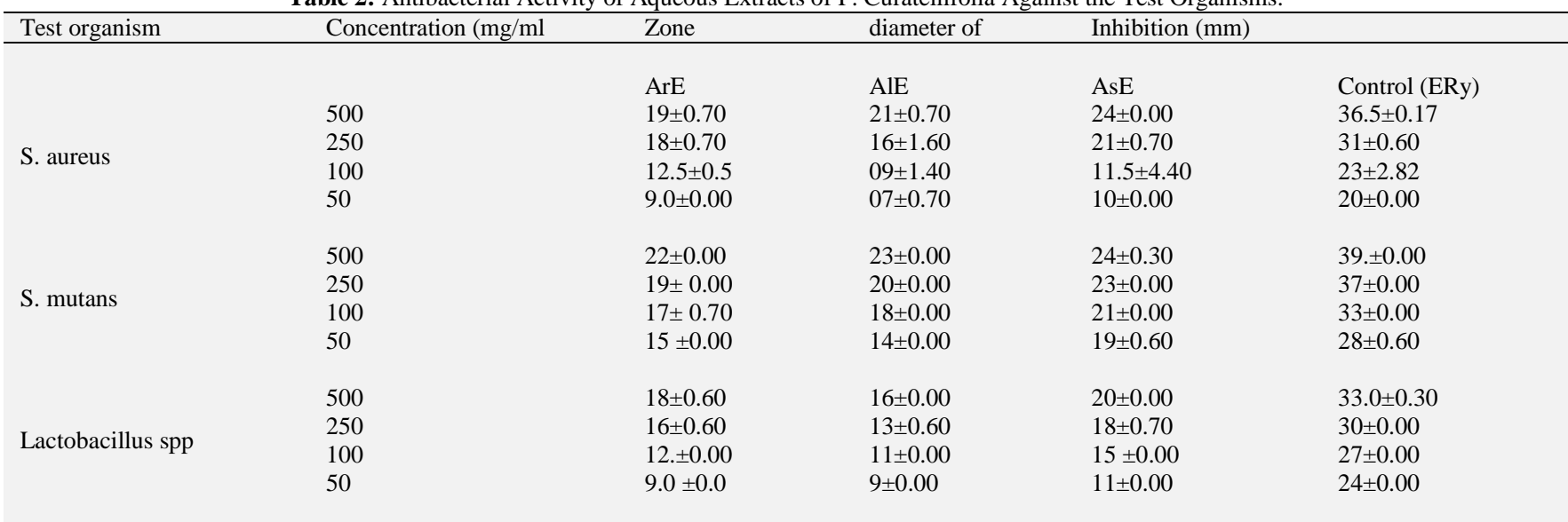

Key: $\mathrm{ArE}=$ aqueous root extract, $\mathrm{AlE}=$ aqueous leaf extract, $\mathrm{AsE}=$ aqueous stem bark extract, ErY=erythromycin

Table 3: Antibacterial Activity of Ethanol Extracts of P. Curatellifolia Against the Test Organisms.

\begin{tabular}{|c|c|c|c|c|c|}
\hline Test organism & Concentration $(\mathrm{mg} / \mathrm{ml})$ & Zone & diameter of & Inhibition (mm) & \\
\hline & & ErE & ElE & EsE & Control (ERy) \\
\hline \multirow[t]{3}{*}{ S. aureus } & 250 & $16 \pm 0.00$ & $14 \pm 0.00$ & $17 \pm 0.90$ & $30 \pm 0.60$ \\
\hline & 100 & $13 \pm 0.00$ & $12 \pm 0.00$ & $14 \pm 0.90$ & $27 \pm 0.60$ \\
\hline & 50 & 10. \pm 0.30 & $10 \pm 0.00$ & $11 \pm 0.00$ & $23 \pm 0.00$ \\
\hline \multirow{3}{*}{ S. mutans } & 250 & $18 \pm 0.00$ & $16 \pm 0.00$ & $22 \pm 0.00$ & $33 \pm 0.00$ \\
\hline & 100 & $15 \pm 0.00$ & $14 \pm 0.60$ & $20 \pm 0.30$ & $31 \pm 0.00$ \\
\hline & 50 & $12 \pm 0.00$ & $12 \pm 0.00$ & $16 \pm 0.30$ & $27 \pm 0.00$ \\
\hline \multirow[t]{2}{*}{ Lactobacillus } & 500 & $18 \pm 0.60$ & $19 \pm 0.00$ & $22 \pm 0.00$ & $33.0 \pm 0.00$ \\
\hline & 250 & $14 \pm 0.00$ & $17 \pm 0.00$ & $20 \pm 0.00$ & $30 \pm 0.90$ \\
\hline \multirow[t]{2}{*}{ spp } & 100 & $11 \pm 0.00$ & $13 \pm 0.30$ & $16 \pm 0.00$ & $27 \pm 0.90$ \\
\hline & 50 & $8.0 \pm 0.0$ & $10 \pm 0.30$ & $13 \pm 0.30$ & $23 \pm 0.00$ \\
\hline
\end{tabular}


Table 4: Antibacterial Activity of Methanol Extracts of P. Curatellifolia Against the Test Organisms.

\begin{tabular}{|c|c|c|c|c|c|}
\hline Test organism & Concentration $(\mathrm{mg} / \mathrm{ml})$ & Zone & diameter of & Inhibition (mm) & \\
\hline \multirow{4}{*}{ S. aureus } & & $\mathrm{MrE}$ & $\mathrm{MlE}$ & MsE & Control (Ery) \\
\hline & 500 & $22.4 \pm 0.90$ & $20 \pm 0.00$ & $23 \pm 0.00$ & $34 . \pm 0.00$ \\
\hline & 100 & $17 \pm 0.30$ & $1.4 \pm 0.00$ & $18 \pm 0.00$ & $29 \pm 0.00$ \\
\hline & 50 & $15 \pm 0.00$ & $11 \pm 0.00$ & $16 \pm 0.00$ & $25 \pm 0.00$ \\
\hline \multirow{3}{*}{ S. mutans } & 500 & $23 \pm 0.00$ & $23 \pm 0.00$ & $24 \pm 0.30$ & $34 \pm 0.00$ \\
\hline & 250 & $21 \pm 0.00$ & $20 \pm 0.00$ & $22 \pm 0.00$ & $31 \pm 0.00$ \\
\hline & 100 & $8.0 \pm 0.70$ & $17 \pm 0.00$ & $20 \pm 0.00$ & $30 \pm 0.00$ \\
\hline \multirow{5}{*}{ Lactobacillus spp } & 50 & $15 \pm 0.0$ & $15 \pm 0.00$ & $17 \pm 0.50$ & $18 \pm 0.50$ \\
\hline & 500 & $20 \pm 0.60$ & $19 \pm 0.00$ & $23 \pm 0.00$ & $33 \pm 0.00$ \\
\hline & 250 & $18 \pm 0.00$ & $14 \pm 0.60$ & $20 \pm 0.70$ & $29 \pm 0.00$ \\
\hline & 100 & $14 \pm 0.00$ & $10 \pm 0.00$ & $16.0 \pm 0.00$ & $26 \pm 0.00$ \\
\hline & 50 & $11.3 \pm 0.90$ & $8.0 \pm 0.00$ & $12 \pm 0.60$ & $22 \pm 0.00$ \\
\hline
\end{tabular}

Key: $\mathrm{MrE}=$ methanol root extract, $\mathrm{MlE}=$ methanol leaf extract, $\mathrm{MsE}=$ methanol stem bark extract, ErY =erythromycin.

Table 5: Minimum Bactericidal Concentration (MBC) of the Aqueous, Ethanol and Methanol Extracts of P. Curatellifolia against the Test Organisms

\begin{tabular}{|c|c|c|c|c|c|c|c|c|c|c|}
\hline Test organisms & Conc & $\mathrm{ArE}$ & AlE & AsE & ErE & ElE & EsE & $\mathrm{MrE}$ & $\mathrm{MrE}$ & $\mathrm{MrE}$ \\
\hline \multirow{3}{*}{ S. mutans } & 500 & - & - & - & - & - & - & - & - & - \\
\hline & 250 & + & - & - & - & - & - & - & - & - \\
\hline & 100 & + & + & - & + & - & + & - & - & - \\
\hline \multirow{5}{*}{ S. aureus } & 50 & + & + & + & + & + & + & + & + & + \\
\hline & 500 & - & - & - & - & - & - & - & - & - \\
\hline & 250 & - & - & - & - & - & - & - & - & - \\
\hline & 100 & + & + & - & + & - & - & - & - & - \\
\hline & 50 & + & + & + & + & + & + & + & + & + \\
\hline \multirow{3}{*}{ Lactobacillus spp } & 250 & + & - & - & + & - & - & - & - & - \\
\hline & 100 & + & + & - & + & - & - & + & - & - \\
\hline & 50 & + & + & + & + & + & + & + & + & + \\
\hline
\end{tabular}

Key: ArE=Aqueous root extract, $\mathrm{AlE}=$ Aqueous leaf extract, AsE = Aqueous stem bark extract, ErE= Ethanol root extract, ElE = Ethanol leaf extract, $\mathrm{EsE}=$ Ethanol stem bark extract $\mathrm{MrE}=$ Methanol root extract, $\mathrm{MLE}=$ Methanol leaf extract and MsE= Methanol stem bark extract. Conc $=\mathrm{mg} / \mathrm{ml}$

Table 6: Antibacterial Activities of the Different Isolates of Methanol Extracts of the Stem Bark of P. Curatellifolia.

\begin{tabular}{|c|c|c|c|c|c|c|c|c|c|c|c|c|}
\hline \multirow{2}{*}{ Organism } & \multicolumn{3}{|c|}{$\mathrm{ME}_{1}$} & \multicolumn{3}{|c|}{$\mathrm{ME}_{2}$} & \multicolumn{5}{|c|}{ ErY } & \multirow[b]{2}{*}{100} \\
\hline & 10 & 25 & 50 & 100 & 10 & 25 & 50 & 100 & 10 & 25 & 50 & \\
\hline S. aureus & $13 \pm 0.00$ & $15 \pm 0.00$ & $21 \pm 0.00$ & $24 \pm 0.00$ & $10 \pm 0.00$ & $14.5 \pm 0.00$ & $17.5 \pm 0.00$ & $20 \pm 0.00$ & $21.3 \pm 0.00$ & $20 \pm 0.00$ & $30 \pm 0.00$ & $33 \pm 0.00$ \\
\hline S. mutans & $15 \pm 0.60$ & $19.7 \pm 0.3$ & $24 \pm 0.00$ & $28 \pm 0.00$ & $9.0 \pm 0.00$ & $12 \pm 0.00$ & $16.3 \pm 0.00$ & $20 \pm 0.60$ & $24 \pm 0.00$ & $28 \pm 0.00$ & $33 \pm 0.00$ & $35 \pm 0.00$ \\
\hline $\begin{array}{l}\text { Lactobacillus } \\
\text { spp }\end{array}$ & 0.00 & $7.0 \pm 0.00$ & $11.0 \pm 0.00$ & $17 \pm 0.60$ & 0.00 & $7.7 \pm 0.30$ & $9.0 \pm 0.17$ & $14 \pm 0.00$ & $17 \pm 0.60$ & $23 \pm 0.00$ & $27 \pm 0.00$ & $30.7 \pm 0.00$ \\
\hline
\end{tabular}

Table 7: Minimum Bactericidal Concentration (MBC) of Different Isolates of Methanol Stem Extracts of P. Curatellifolia

\begin{tabular}{|c|c|c|c|}
\hline Test organisms & Concentration $(\mathrm{mg} / \mathrm{ml})$ & $\mathrm{ME}_{1}$ & $\mathrm{ME}_{2}$ \\
\hline \multirow{4}{*}{ S. aureus } & 100 & - & - \\
\hline & 50 & - & - \\
\hline & 25 & - & - \\
\hline & 10 & - & + \\
\hline \multirow{4}{*}{ S. mutans } & 100 & - & - \\
\hline & 50 & - & - \\
\hline & 25 & - & - \\
\hline & 10 & - & - \\
\hline \multirow{3}{*}{ Lactobacillus spp } & 50 & - & - \\
\hline & 25 & + & + \\
\hline & 10 & + & + \\
\hline
\end{tabular}

Key: $\mathrm{ME}_{1}=$ methanol extract fraction, $\mathrm{ME}_{2}=$ Second methanol extract fraction,

\section{Discussion}

Phytochemical screening of the crude extracts (root, leaf and stem bark) of P.curatellifolia revealed the presence of saponins, tannins, alkaloids, flavonoids, glycosides, cardiac glycoside, resins however, balsam, cardiac glycoside, glycoside, flavoniods were absent in the aqueous leaf and root extracts. The antibacterial activities that were observed to be displayed by the extracts of the different plant parts materials may be attributed to the presence of these plant metabolites(Sofowora 1993; .Arokiyarraij et.al., 2009).The antibacterial assay of crude plant extracts, $\mathrm{ME}_{1}$ and $\mathrm{ME}_{2}$ (table 2, 3 \& 4) exhibited activities against S. aureus, S. mutans and Lactobacillus spp. The differences in the different zone diameter of inhibition reflect the varying degree of sensitivity of the bacteria to the crude extracts and the isolates. Streptococcus mutans was highly sensitive to the methanol stem bark extract and Staphylococcus aureus was moderately sensitive and Lactobacillus spp was less sensitive (Table 2). The result of the antibacterial assay of the plant extracts is comparable to Erythromycin the standard antibacterial agent used as the positive control in this work. These results suggest that the extracts of P. curatellifolia can be further enhanced for the treatment of dental caries (tooth decay) and wound infections which have shown by other researchers to be caused by Streptococcus mtans, Lactobacillus spp and Staphy- 
lococcus aureus respectively. The minimum inhibitory concentration (MIC) and minimum bactericidal concentration (MBC) of the extracts of P.curatellifolia on the test organisms are of great significance, since these multidrug resistant organisms are of great epidemiological threat. The low MIC value confirms the high antibacterial activity of the extracts at different concentrations. The isolates $\left(\mathrm{ME}_{1}\right.$ and $\left.\mathrm{ME}_{2}\right)$ of the methanol extract exhibited significant antibacterial activities, $\mathrm{ME}_{1}$ showed $28 \pm 0.00 \mathrm{~mm}$ against $\mathrm{S}$. mutans. However, the inhibition zones were significantly $(\mathrm{P}<0.05)$ higher than that observed with the crude extract. Isolate $\mathrm{ME}_{1}$ showed high activity against all the test organisms. These results have demonstrated that $\mathrm{ME}_{1}$ possess high efficacy compared to the crude extract. Isolate $\mathrm{ME}_{1}$ could serve as a broad spectrum antibacterial agent and paving way for further investigation to identify the active compounds responsible for the plant biological activity with the required MIC for use in drug development for safe health care delivery.

\section{Conclusion}

The presence of the metabolites in the plant extracts, enhance the activity of combined agents of the solvent on susceptible microbes. The crude extract of P. curatellifolia displayed significant activity against the test organisms that is, S. aureus, S. mutans and Lactobacillus spp. The phytochemicals and antibacterial activities exhibited by the extracts of Parinari curatellifolia serve as a potential antibacterial agent and confirm the folkloric uses of the plant in medicine.

\section{References}

[1] Srivastav, D. Nathan, S. and Suresh, T. (2001). Antimicrobial activity of Certain Medical plants using in folkloric medicine. Journal Ethnophanacology 74: 217-222. http://dx.doi.org/10.1016/S0378-8741 (00)00345-7.

[2] Mark, H. and Bart, W. (2002). Flora of Zimbabwe: Species information: P. curatellifolia. www,Zimbabwe.co.Zw/species data/species

[3] Shale, T. L. WA, A., Stirk, J. Van. Steden, (1999). Screening of medicinal plants used in Lesotho for antibacterial and ant -inflammatory activity. Journal of Ethnopharmacology, 67: 347- 354 http://dx.doi.org/10.1016/S0378-8741 (99)00035-5.

[4] Qasem, J.R. and Abubakan, H.A. (1996). Fungicidal activity of some neem extracts against different plant pathogenic fungi. Journal of phytopathology, 44 (3): 157-16. http://dx.doi.org/10.1111/j.14390434.1996.tb01507.x.

[5] Kraft, c., Jenett-Siems, K., Jakupovic, J., Mavi, s., Bienzle, U and Elich, E. (2003). Invitro antiplasmodial. Evaluation of Medicinal Plants from Zimbabwe. Phytotherapy Resaerch 17 (2):123-128.

[6] Steve, O.O., Sunday, O.O., Emmanuel, N.A., Veronica, N.E and Olawale, O.P (2009). Evaluation of acute toxicity in mice and subchronic toxicity of hydroethanolic extract of $P$. Curatellifolia. Planch (Chrysobalanaceae) seeds in rats. African Journal of Biotechnology, 8 (9), 1800-1806.

[7] Peni, I.J., Elinge, C.M., Yusuf, H., Itodo, A.U, Agaie, B.M., and Mbongo, A.N. (2010). Phytochemical screening and antibacterial activity of Parinari curatellifolia stem extract. Journal of Medicinal Plants Research.

[8] Edeoga, H., Okwu, D. and Mbaebi, B. (2005).Phytochemical constituents of some Nigerian medicinal plants. Africa Journal of Biotechnology, 4:685-688. http://dx.doi.org/10.5897/AJB2005.000-3127.

[9] Harborne, J.B. (1998). Phytochemical method: A guide to modern Techniques of plant analysis. London: Chapman and Hall Publishers, Pp51-59.

[10]Evan, W.C, Trease G.E (1983). Textbook of Pharmacognosy, 12th edition, Balliere, London.pp14-25.

[11]Halilu, M.E., Yebpella, G.G., Hassan, L.G., and Achor, M. (2010) Preliminary phytochemical screening, antibacterial activity and elemental analysis of the leaves and the root bark of Parinari curatellifolia. Planch Ex Benth (Chrysobalanaceeae) Continental Journal of Pharmaceutical Science 4:1-5.

[12]Rodrigues, H.G., Diniz, Y.S., Faine, L.A., Galhardi, C. M., Burneiko,R.C., Almeida, J.A., Ribas, B.O. and novella, E.L.B. (2005). Antioxidant effect of saponins: potential action of a soybean flavonoid on glucose tolerance and risk factors for atherosclerosis. International
Journal of food science nutrition, 56: 79-85. http://dx.doi.org/10.1080/09637480500081738.

[13]Bukar, A., Uba, A, and Oyeyi, T.I. (2010). Antimicrobial profile of Moringa oleifera Lam extracts against some food-borne microorganisms. Bayero journal of Pure Applied Science, 3(1):43-48.

[14] Sofowora (1993). Medicinal plants and Traditional medicine in Africa. John wiley \& sons New York. Pp. 97-145

[15] Arokiyarraij, K., Perinbam, P., Agastian, R. and Mohan, K. (2009). Phytochemical analysis and antimicrobial activity of vitex agnus castus. International Journal of Green pharmacy, 34(3): 162-164. 